\title{
Optimization of Biogas Generation from Press Mud in Batch Reactor
}

\author{
M. A. Rouf ${ }^{a}$, P. K. Bajpai ${ }^{b}$ and C. K. Jotshic \\ ${ }^{a}$ Institute of Fuel Research and Development, BCSIR, Dr. Qudrat-I- Khuda Road, Dhanmondi, \\ Dhaka-1205, ${ }^{b}$ Thapar Centre for Industrial Research \& Development, Patiala, India and ${ }^{c}$ Advanced \\ Technologies and Testing Lab. Inc 4445SW35 terrace, Suite 270 Gainesville, Florida, 32608
}

\begin{abstract}
Press mud collected from sugar mills in Punjab, India were characterized and found to contain 75-80\% organic matter, which mainly consists of cellulose, hemicellulose, lignin, protein, sugar, wax, etc. Biogas generation from press mud in a 2-litre batch reactor was studied at

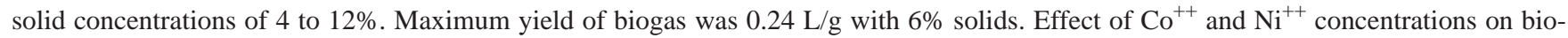
gas yield was also studied. It was maximum at $5 \mu$ moles $/ \mathrm{L}$ of $\mathrm{Co}^{++}$and $6 \mu$ moles $/ \mathrm{L}$ of $\mathrm{Ni}^{++}$. The optimum $\mathrm{C} / \mathrm{N}$ ratio for biogas generation was 18, which was higher than the normal $\mathrm{C} / \mathrm{N}$ ratio of 14 in the press mud. Other substrates such as cow dung, bagasse and cane pith when mixed with press mud in different proportions have influenced biogas generation. Press mud when mixed with cow dung, biomethanation process became more stable. Particularly, cane pith when mixed with press mud in 1:1 ratio, the generation of biogas increased significantly. The methane content of the biogas was about $65 \%$.
\end{abstract}

Key words: Anaerobic digestion, Press mud, Biogas

\section{Introduction}

The press mud (also called filter cake) is a solid waste, generated on clarification of cane juice before its concentration and sugar crystallization. It is a soft, spongy, lightweight, amorphous, dark brown to black coloured material. It generally contains 60-85\% moisture (w/w); the chemical composition depends on cane variety, soil condition, nutrients applied in the field, process of clarification adopted and other environmental factors. During the clarification of cane juice using sulphitation process, most of the non-sugar components are precipitated by addition of milk of lime and sulphur dioxide. The precipitate is allowed to settle in a clarifier and the settled sludge is filtered by using rotary vacuum filter. The amount of sulphitation process mud cake is about $3-4 \%$ of the weight of the cane crushed (Rao, 1997). It is generally used as a fertilizer.

Due to sugar and other organic constituents, the press mud emits obnoxious odour causing environmental pollution. The press mud, at many places, is being used as a fuel. The possibility of using a mixture of filter cake and bagasse in different proportions has been studied to use the mixture as a fuel in the boilers for the generation of steam [Elkader and Yassin, 1989]. It can be burnt directly in the form of bri-

\footnotetext{
* Corresponding author: E-mail:
}

quettes. On burning, it emits toxic gases $\mathrm{SO}_{2}$ and $\mathrm{SO}_{3}$, which pollute the environment. Briquettes of press mud when used in boiler as a fuel, it forms clinkers.

The present methods for disposal of press mud are not economically suitable and pollute the environment. As it contains appreciable proportion of biodegradable organic matter, it has very good potential for the production of biogas. In addition, the digested slurry can be used as a good quality fertilizer. Although few biogas plants, based on press mud, are in operation, their performance is not satisfactory due to the presence of wax and problem of fast acidification. Only few studies have been reported on the anaerobic biomethanation of press mud [Nunez and Silva, 1983: Sanchez et al., 1996]. Attempts have also been made to produce the biogas (methane) from filter cake by mixing it with bagasse [Dasgupta and Nemerow, 1988] and agricultural and other wastes (Mudamwar et al., 1990).

Rouf et al. (1999) reported earlier the characterization of press mud and its potential for biogas generation. In the present study, optimization of biogas generation from press mud and by mixing it with other wastes/residues, and effects of various parameters has been investigated. 


\section{Materials and Methods}

\section{Substrate}

The press mud samples were collected from sugar mills in Punjab during the period between Novembers to March, as it is available only during the harvesting period of sugar cane. The samples were stored in a cold room, maintained at $4^{\circ} \mathrm{C}$, before analysis and other experiments.

\section{Anaerobic Biomethanation}

The collected press mud sample was diluted to different solid concentrations in a 2-litre capacity wide mouth glass bottle. Volume of the substrate in the bottle was one litre. It was inoculated with the sludge collected from an anaerobic digestion plant (for municipal sewage waste) and pre-acclimatized with press mud for 30 days. The bottle was kept in a room, maintained at $37^{\circ} \mathrm{C}$. Volume of the gas generation was measured by the water displacement technique.

\section{Analytical Methods}

Carbon and nitrogen contents in the press mud were determined with the help of a C-H-N elemental analyzer. Its moisture and ash contents were estimated by gravimetric methods by drying at $105{ }^{\circ} \mathrm{C}$ and by complete combustion at $800^{\circ} \mathrm{C}$, respectively. Volatile matter and calorific value were determined according to IS:10158-1982 and IS:1350(Part 4)-197 by bomb calorimeter, respectively. For estimation of fibre content, about $20 \mathrm{gm}$ of press mud was weighed accurately and washed over a tared 200 mesh sieve until the water run clear. Excess water is drained off and the sieve along with its contents was dried in an oven at $105^{\circ} \mathrm{C}$ to a constant weight. Fibre content is calculated from the increase in weight of the tared sieve (Mathur, 1997).

Chemical oxygen demand (COD) of the sample was estimated by oxidising the substrate with potassium dichromate and then titrating by ferrous ammonium sulphate [APHA, 1992]. Extracting with benzene in a Soxhlet apparatus and then distilling it to remove the benzene and quantitatively recovering the wax measured the wax content. Sugar content in the press mud sample was determined by measuring the optical rotation of the filtrate solution of 25 gm press mud in 200 $\mathrm{mL}$ water using polarimeter. Sodium, potassium and calcium contents were determined by flame photometer according to IS: 10614-1983 and other metals by atomic absorption spectrophotometer (GBC, Australia make). Phosphate content was determined according to IS: 6361-1971. The protein content was estimated from the nitrogen content by multiplying it with 6.25.

Methane and carbon dioxide contents in the biogas samples were analyzed by gas chromatographic technique using Porapak Q column and thermal conductivity detector. Analytical grade hydrogen was used as a carrier gas.

\section{Results and Discussion}

\section{Characteristics of Press Mud}

General characteristics of press mud sample are given in Table I. The moisture content in the samples varied from 74.9 to $78.7 \%$ (averaging $76.3 \%$ ). The press mud used for generation of biogas contained about $77 \%$ volatile solids. The $\mathrm{C} / \mathrm{N}$ ratio was $\sim 14$. The organic matter present in the press mud consisted mainly of cellulose $11.4 \%$, hemicellulose $10 \%$, lignin $9.3 \%$, protein $15.1 \%$, wax $8.4 \%$ and sugar $5.7 \%$ (Table I). It also contained various micronutrients as shown in Table II. The COD and $\mathrm{pH}$ of $6 \%$ press mud slurry were $50.6 \mathrm{~g} / \mathrm{L}$ and 7.1 respectively. In fact, the chemical composition of press mud depends on the cane variety, soil conditions, nutrients applied in the field, process of clarification adopted and other environmental factors.

\section{Table I: Characteristics of press mud samples}

\begin{tabular}{l|l|c}
\hline Sr. No. & Parameter & Average Value \\
\hline 1 & Moisture (\%) & 76.3 \\
2 & Solids (\%) & 23.8 \\
3 & Volatile Matter (\%) & 76.6 \\
4 & Ash (\%) & 22.4 \\
5 & Wet Bulk Density & 0.76 \\
6 & Fibre (\%) & 23.6 \\
7 & Sugars (\%) & 6.4 \\
8 & Wax (\%) & 7.2 \\
9 & Protein (\%) & 15.8 \\
10 & Calorific Value (kcal/kg) & 3861 \\
11 & C/N Ratio & 14.0 \\
12 & pH of 10\% solids & 7.5 \\
13 & COD of 10\% solids (g/L) & 86.9 \\
\hline
\end{tabular}

\section{Acclimatization of Inoculum}

Inoculum (digested sludge) was collected from a municipal sewage treatment plant at Okhla, New Delhi, India. The inoculum was acclimatized to press mud for 30 days. This acclimatized inoculum was able to successfully produce biogas from the press mud. Whereas direct inoculation with 
digested municipal sewage sludge did not prove successful in biogas generation.

Table II: Composition of press mud

\begin{tabular}{l|l|c}
\hline Sr. No. & Component & \% age (dry basis) \\
\hline 1 & Cellulose & 11.4 \\
2 & Hemicellulose & 10.0 \\
3 & Lignin & 9.3 \\
4 & Protein & 15.1 \\
5 & Wax & 8.4 \\
6 & Sugar & 5.7 \\
7 & Micronutrients & \\
& Na & 0.22 \\
& K & 0.40 \\
& Ca & 2.11 \\
& $\mathrm{Mg}$ & 0.33 \\
& $\mathrm{Fe}$ & 0.32 \\
& $\mathrm{Zn}$ & 0.01 \\
& $\mathrm{C} 0$ & Trace \\
& $\mathrm{Ni}$ & 0.02 \\
& $\mathrm{Cr}$ & 0.01 \\
& $\mathrm{Mn}$ & 0.04 \\
\hline
\end{tabular}

\section{Effect of Solid Concentration}

Studies on biogas generation in a 2-litre batch reactor were carried out with solid concentrations of 4, 6, 8, 10 and 12\% of press mud. The maximum biogas yield of $0.241 \mathrm{~L} / \mathrm{g}$ was obtained with $6 \%$ solids as shown in Fig. 1. Higher solids gave progressively greater accumulation of volatile fatty

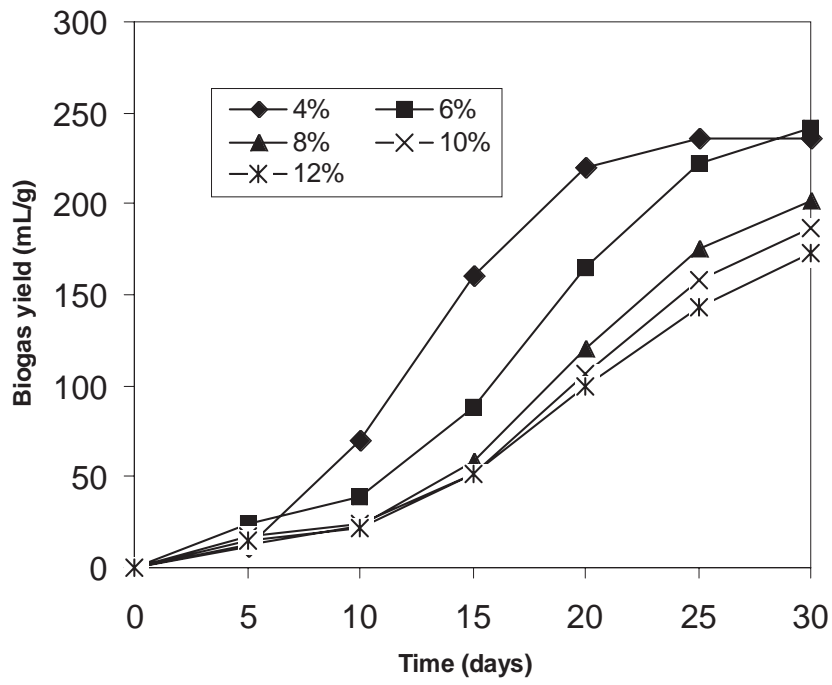

Fig. 1: Biogas yield at different solid concentrations acids (results not shown), and thus the lower pH led to progressively lower gas yield. The reduction of gas yield at higher solid concentrations could also be due to poor mixing of bacterial cell with the solids in the slurry.

\section{Effect of Temperature and $\mathrm{pH}$}

The effect of temperature on biogas yield was studied from 25 to $45{ }^{\circ} \mathrm{C}$. The maximum biogas yield was found at $35-40^{\circ} \mathrm{C}$ as expected; the optimum temperature for anaerobic treatment is known to be $37^{\circ} \mathrm{C}$. The rate of gas production was relatively lower at temperatures less than $30^{\circ} \mathrm{C}$ or more than $40^{\circ} \mathrm{C}$ which did not favour the methanogenesis by mesophilic bacteria.

The $\mathrm{pH}$ is another important parameter for biogas production. Biogas generation from press mud was observed at $\mathrm{pH}$ values of $6.5,7.0,7.5,8.0$ and 8.5 . It was maximum in the $\mathrm{pH}$ range of 7.0-7.5 as expected.

\section{Effect of Carbon/Nitrogen (C/N) Ratio}

Biogas generation was studied at $\mathrm{C} / \mathrm{N}$ ratio of $14,16,18,20$ and 22. Cellulose powder was used to increase the $\mathrm{C} / \mathrm{N}$ ratio as press mud has a low $\mathrm{C} / \mathrm{N}$ ratio of about 14 . The $\mathrm{C} / \mathrm{N}$ ratio of 18 was found to be optimum for biogasification of press mud as shown in Fig. 2. Gas yield at optimum $\mathrm{C} / \mathrm{N}$ ratio was $0.267 \mathrm{~L} / \mathrm{g}$. Press mud has a $\mathrm{C} / \mathrm{N}$ ratio of about 14 which is little lower than the optimum.

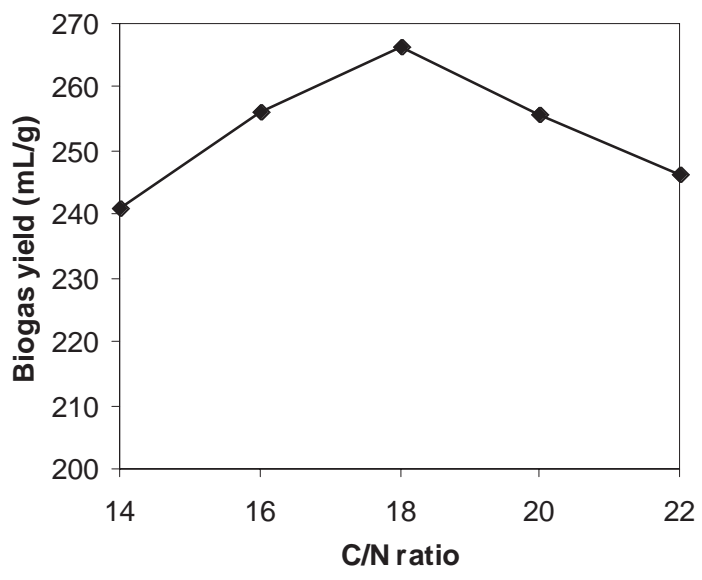

Fig. 2: Biogas yield at different $\mathrm{C} / \mathrm{N}$ ratio

The $\mathrm{C} / \mathrm{N}$ ratio of the substrate is an important parameter for the biogas production. On the one hand, biodegradation of nitrogenous compounds contributes to the neutral $\mathrm{pH}$ stability by the release of ammonium cations. On the other hand, 
the nitrogen is also important for bacterial cell growth, which is an important phenomenon in the whole process of biomethanation. At low $\mathrm{C} / \mathrm{N}$ ratio, carbon addition stimulates methane production by reducing ammonia inhibition. At high $\mathrm{C} / \mathrm{N}$ ratio, carbon addition decreases the methane yield as nitrogen becomes a limiting nutrient and bacteria suffer a nutrient deficiency. The methane content of biogas also depends on the $\mathrm{C} / \mathrm{N}$ ratio. At higher $\mathrm{C} / \mathrm{N}$ ratio, the percentage of methane decreases in the biogas.

For optimum methanogenic performance, $\mathrm{C} / \mathrm{N}$ ratio of the substrate needs to be changed quite often. It can be increased by adding cellulose powder as a source of carbon and can be decreased by adding commercial nitrogen containing compounds like urea. The $\mathrm{C} / \mathrm{N}$ ratio can also be modified by mixing one substrate with the other one of complimentary $\mathrm{C} / \mathrm{N}$ ratio.

\section{Effect of Mixing Other Substrates with Press Mud}

The $\mathrm{C} / \mathrm{N}$ ratio of press mud is 14 , which is lower than the optimum required for biomethanation. To increase the $\mathrm{C} / \mathrm{N}$ ratio and to understand the interaction of press mud with other substrates, various substrates (wastes) were mixed with press mud in different proportions as given below.

1. Press mud and cow dung in the ratio of $2: 1$ and $1: 1$

2. Press mud and bagasse in the ratio of $2: 1$ and $1: 1$

3. Press mud and cane pith in the ratio of $2: 1$ and $1: 1$

Table III. Composition of different substrates

\begin{tabular}{l|c|c|c}
\hline Substrate & $\begin{array}{c}\text { Moisture } \\
(\%)\end{array}$ & $\begin{array}{c}\text { Total solids } \\
\text { (\%) }\end{array}$ & $\begin{array}{c}\text { Volatile } \\
\text { solids (\%) }\end{array}$ \\
\hline Press mud & 77.8 & 22.2 & 77.1 \\
Cow dung & 75.1 & 24.9 & 77.2 \\
Kitchen waste & 88.6 & 11.4 & 92.0 \\
Bagasse & 49.0 & 51.0 & 97.5 \\
Cane pith & 66.1 & 30.9 & 97.2 \\
\hline
\end{tabular}

The composition of different substrates is given in Table III. Gas yield and stability of reactor was observed by noting the change in $\mathrm{pH}$ with time. Degradation of volatile solids, gas yield and gas compositions are given in Table IV. The biogas yield was $0.202 \mathrm{~L} / \mathrm{g}$ in 30 days when press mud and cow dung were mixed in 2:1 ratio. The yield decreased to 0.167 $\mathrm{L} / \mathrm{g}$ when cow dung content was increased to make a mixture in the ratio of $1: 1$. However, with both mixtures, the gas yield was lower as compared to that with press mud alone (Fig. 3). Nevertheless, the reactor became more stable as cow dung has more buffering capacity as compared to press mud although it has lower potential of biogas generation.

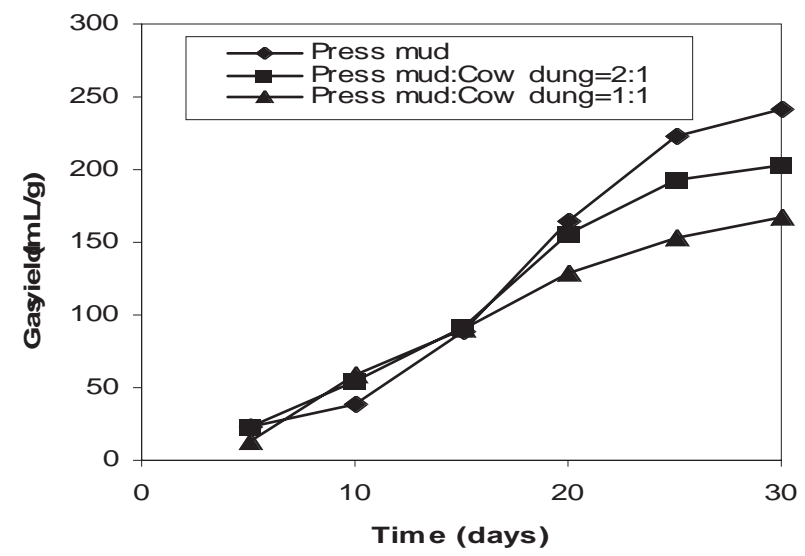

Fig. 3. Biogas generation from press mud by mixing with cow dung

Biogas yield from the mixtures of press mud with bagasse and with cane pith are given in Figs. 4 and 5. Gas production increased significantly (by 58\%) when the press mud was mixed with cane pith in the ratio of $1: 1$.

\section{Effect of $\mathrm{Co}^{++}$and $\mathrm{Ni}^{++}$}

The $\mathrm{Co}^{++}$concentration of $4-20 \mu \mathrm{M} / \mathrm{L}$ and $\mathrm{Ni}^{++}$concentration of $3-12 \mu \mathrm{M} / \mathrm{L}$ was added in the press mud slurry $(6 \%$ solids) to observe its effect on biogas generation. $\mathrm{Co}^{++}$con-

Table IV: Volatile solids (VS) degradation, gas yields and gas composition

\begin{tabular}{l|c|c|c}
\hline Substrate & VS degradation (\%) & Gas yield (L/g) & Methane (\%) \\
\hline Press mud & 49.4 & 0.241 & 64.1 \\
Press Mud: cow dung (2:1) & 39.5 & 0.202 & 64.2 \\
Press mud: cow dung (1:1) & 33.3 & 0.167 & 63.4 \\
Press mud: bagasse (2:1) & 48.4 & 0.263 & 64.3 \\
Press mud: bagasse (1:1) & 53.3 & 0.273 & 64.4 \\
Press mud: cane pith (2:1) & 56.3 & 0.290 & 65.6 \\
Press mud: cane pith (1:1) & 69.2 & 0.381 & 66.8 \\
\hline
\end{tabular}




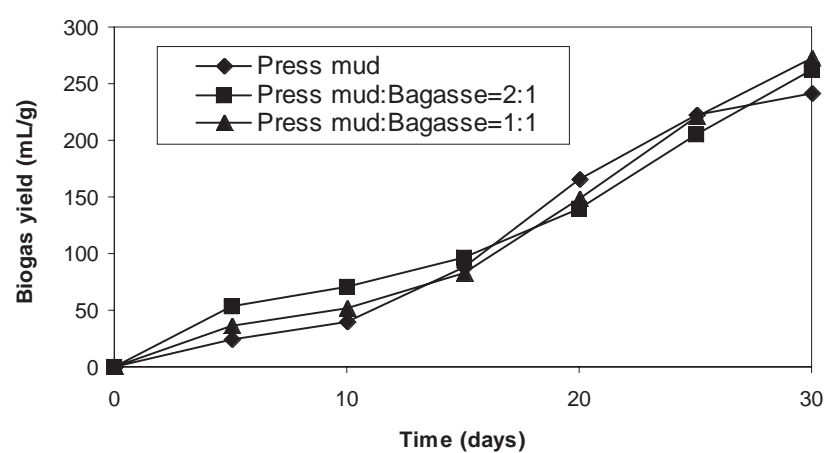

Fig. 4: Generation of biogas from press mud by mixing with bagasse

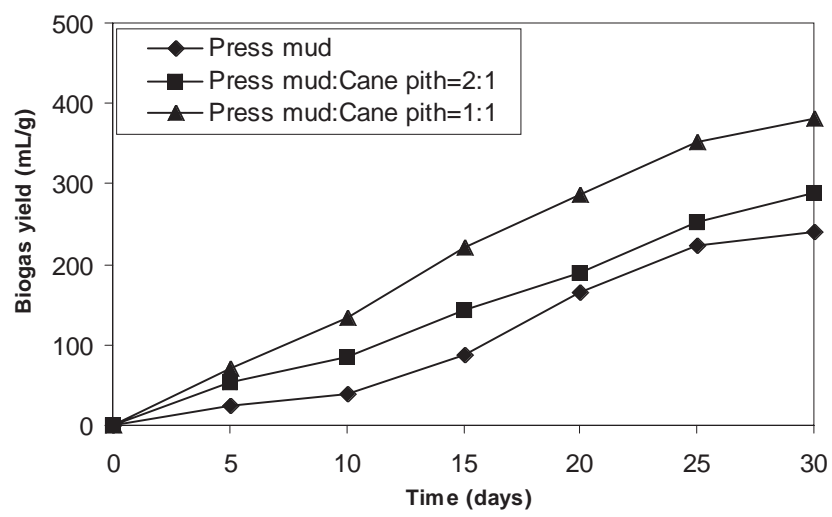

Fig. 5: Biogas generation from press mud by mixing with cane pith

centration of $5 \mu \mathrm{M} / \mathrm{L}$ was found to be optimum which increased the gas production by $\sim 9 \%$ over that of control. Similarly, optimum $\mathrm{Ni}^{++}$concentration was found to be around $6 \mu \mathrm{M} / \mathrm{L}$, giving about $9 \%$ more gas over that of control. At optimum concentrations of $\mathrm{Ni}^{++}$and $\mathrm{Co}^{++}$, the biogas yield increased by $\sim 14 \%$ as compared to that without addition of these trace metals. Both $\mathrm{Co}^{++}$and $\mathrm{Ni}^{++}$showed inhibition at higher concentrations.

\section{Effect of Other Parameters}

Mixing of the reactor mass is also important for biomethanation. Occasional stirring (2-3 times a day) for few minutes or continuous stirring at a low speed helped in biogas generation. By mixing, the interaction between bacterial cells and solid substrates is expected to be better, thereby increasing the biogas generation. However, continuous stirring at high speed was found to be not favourable. It appears that by continuous mixing at high speed results in excessive shearing effect on the microbial cells. This in turn reduces the concentration of viable cell mass, which ultimately influences the biogas production.
Reducing the particle size of the press mud to smaller size was found to improve the rate of biogas generation, probably due to increase in surface area of the solid particles, which results in better contact of bacterial mass with the solid substrate. Particle size of minus 25 mesh was found to be optimum.

Crude wax of press mud contains fats, oils, and hard wax, which is hydrophobic in nature and forms scum on the surface of the reactor. The wax content of the press mud was reduced from $8.4 \%$ to $3.8 \%$ and then used for biogas generation. The yield of biogas decreased by $21.6 \%$. Although removal of crude wax decreased the scum formation in the reactor, it decreased the yield of biogas. In fact, the $\mathrm{C} / \mathrm{N}$ ratio of the substrate decreased to 12.5 on removing the wax, which was not favourable to biomethanation process. This resulted in the decreased yield of biogas to $0.189 \mathrm{~L} / \mathrm{g}$. A part of the crude wax was also found to be degraded by anaerobic bacteria.

\section{Conclusion}

The press mud contains $~ 77 \%$ volatile solids, which are biodegradable in nature, and a good proportion of nitrogen (C/N ratio of 14 ). This makes it a very good material for generation of bioenergy (methane) by anaerobic biomethanation.

The optimum conditions for biogas generation from press mud are: solid concentration $6 \%, \mathrm{C} / \mathrm{N}$ ratio $18, \mathrm{pH} 7.0-7.5$, and temperature $35-40^{\circ} \mathrm{C}$. Optimum concentration of micronutrients, $\mathrm{Co}^{++}$and $\mathrm{Ni}^{++}$, are 5 and $6 \mu \mathrm{M} / \mathrm{L}$ respectively. Reduction of the solid particles to minus 25 mesh size improves the biogas yield. Fast acidification due to conversion of sugar into volatile fatty acids and low buffering capacity in addition to lower $\mathrm{C} / \mathrm{N}$ ratio are the main problems of press mud for biomethanation. Mixing of other substrates of high $\mathrm{C} / \mathrm{N}$ ratio like cow dung, bagasse and cane pith can result in optimum $\mathrm{C} / \mathrm{N}$ ratio. This will also reduce the acidification problem and increase the buffering capacity. Mixing of cane pith in the ratio of 1:1 gives best performance of the reactor and biogas yield.

Partial removal of crude wax from the press mud can reduce the problem of scum formation. This also reduces the $\mathrm{C} / \mathrm{N}$ ratio, which can be increased to the optimum level of 18 by mixing it with cane pith, also available in the sugar mill. The digested slurry of press mud, which is rich in plant nutrients, can be used as a fertilizer. 


\section{References}

APHA AWWA and WEF (1992). Standard Methods for the Examination of Water \& Wastewater, (18th Edn.), American Public Health Assn., Washington, DC

Dasgupta A. and Nemerow N. L. (1986). Anaerobic Digestion of Lignocellulosic Residue from Sugarcane Processing, Energy Biomass Waste, 11: 613

Desdin L., Gonzalez D. and Labrada A. (1995). Moisture Measurement in the Filter Press Mud by Gamma Transmission Method, J. Radiational. Nucl. Chem., 201(4): 321.

Elkader A. A. and Yassin A. A. (1989). Filter Mud as Fuel for Steam Generation in Egypt, Proc. of the XX Congress of ISSCT, p. 326.

Mathur R. B. L. (1997). Handbook of Cane Sugar Technology, IBH Publishing Co., New Delhi, p. 248.

Mudamwar D., Patel V. and Patel A. (1990). Effect of Agricultural and Other Wastes on Anaerobic Digestion of Water hyacinth-Cattle dung, J. Ferment. Bioeng. 70(5): 343.
Nunez A. G. and Silva L. (1983). A study on the Production of Biogas from Filter Press Mud, Proc. of the XVIII Congress of ISSCT, p. 1499.

Rao P. J. M. (1997). Industrial Utilization of Sugar Cane and Its Co-products, ISPCK Publishers, Delhi, p. 472.

Rouf M. A., Bajpai P. K. and Jotshi C. K. (1999). Characterization of Press Mud from Sugar Industry and Its Potential for Biogas Generation, Proc. CHEMCON-99 (Indian Chemical Engineering Congress), Chandigarh, December 20-23, pap. RMA-158).

Sanchez E., Borja R. and Lopet M. (1996). Determination of the Kinetic Constants of Anaerobic Digestion of Sugar Mill Mud Waste, Bioresouce Technol. 56(2\&3): 245.

Received : August 14, 2008;

Accepted : February 11, 2010 